\title{
Analisis Tujuan Dan Filsafat Kurikulum Sekolah Tinggi Keguruan Dan Ilmu Pendidikan Weetebula Dalam Perspektif Pengembangan Kurikulum Oliva-Gordon
}

\author{
Agustinus Tanggu Daga ${ }^{1}$ \\ ${ }^{1}$ Program Studi Pengembangan Kurikulum SPS, Universitas Pendidikan Indonesia, Bandung.
}

\author{
*Agustinus Tanggu Daga: \\ Program Studi Pengembangan \\ Kurikulum SPS, Universitas \\ Pendidikan Indonesia, Bandung; \\ Email: agus_daga@yahoo.com
}

\begin{abstract}
Abstrak: Tujuan dan filsafat kurikulum memberikan landasan dan arah terhadap implementasi kurikulum pada institusi pendidikan. Para ahli kurikulum telah menjelaskan tujuan dan filsafat kurikulum dalam desain kurikulum yang diimplementasikan praktek pendidikan. Penelitian ini bertujuan menjelaskan pandangan Oliva-Gordon tentang tujuan dan filsafat pengembangan kurikulum dalam implementasi kurikulum di STKIP Weetebula. Metode stusi literatur digunakan untuk mengumpulkan data dari berbagai sumber yang relevan. Penelitian ini menunjukan bahwa tujuan pendidikan dalam kurikulum meliputi tujuan umum, pernyataan tujuan, dan asal dari tujuan. Sedangkan filsafat pendidikan dalam kurikulum meliputi rekonstruksionisme, progresivisme, esensialisme, dan perenialisme. Tujuan pendidikan dalam kurikulum STKIP Weetebula termuat secara eksplisit dan implisit dalam visi, misi, dan tujuan STKIP Weetebula. Sedangkan filosofi kurikulum STKIP Weetebula tercermin dari karakteristik STKIP Weetebula yang disebut sebagai nilai-nilai inti dan semboyan "bersama kita bisa". Dokumen-dokumen kurikulum pada level program studi menjabarkan tujuan dan filsafat pendidikan tersebut dan dimplementasikan dalam berbagai praktik pendidikan di STKIP Weetebula.
\end{abstract}

Kata Kunci: Kurikulum, Filsafat, dan Tujuan

Abstract: The goals and philosophy of the curriculum provide the foundation and direction for curriculum implementation in educational institutions. Curriculum experts have explained the objectives and philosophy of the curriculum in curriculum design that is implemented in educational practice. This research aims to explain the Oliva-Gordon perspective on the goals and philosophy of curriculum development in curriculum implementation at STKIP Weetebula. The literature study method was applied to collect the data from various relevant resources. This research shows that the goals of education in the curriculum include global aims, statement of purposes, and the derivation of aims. Meanwhile, the educational philosophy in the curriculum includes reconstructionism, progressivism, essentialism, and perennialism. The educational goals in the Weetebula STKIP curriculum are contained explicitly and implicitly in the vision, mission, and objectives of the Weetebula STKIP. Meanwhile, the philosophy of the Weetebula STKIP curriculum is reflected in the characteristics of the Weetebula STKIP which are referred to as core values and the slogan "bersama kita bisa". Curriculum documents at the study program level describe the aims and philosophy of education and are implemented in various educational practices at STKIP Weetebula.

Key word: Goals, Curriculum, and Philosophy 


\section{PENDAHULUAN}

Kurikulum memiliki kedudukan, fungsi, dan peran strategis dalam pendidikan pada berbagai jenis dan jenjang pendidikan. Kualitas pendidikan sangat ditentukan oleh kualitas kurikulumnya. Salah satu variabel penting dan menentukan upaya peningkatan kualitas pendidikan adalah kualitas kurikulum. Karena itu rumusan kurikulum yang berkualitas memiliki pengaruh signifikan terhadap kualitas pendidikan. Tuntutan kualitas pendidikan merupakan tantangan dalam desain dan implementasi kurikulum. Kurikulum menjadi 'jantung' dari pendidikan. Dalam pandangan Oliva \& Gordon (2013, hlm. 7) kurikulum merupakan rencana atau program untuk semua pengalaman yang diperoleh peserta didik di bawah bimbingan sekolah. Kurikulum dalam praktiknya terdiri dari sejumlah rencana dalam bentuk tertulis dan cakupan yang bervariasi yang menggambarkan pengalaman belajar yang diharapkan. Kurikulum dapat berupa unit, mata kuliah, urutan mata kuliah, seluruh program studi di sekolah - dan dapat ditemui di dalam atau di luar kelas atau sekolah yang dibimbing oleh personel sekolah.

Kurikulum menjadi acuan dalam menata dan mengarahkan segala bentuk aktivitas pendidikan untuk mencapai tujuan-tujuan pendidikan. Alawiyah (2013, hlm. 65) menyatakan bahwa kurikulum merupakan komponen dalam pendidikan yang menjadi panduan dalam melaksanakan pembelajaran baik pada tatanan satuan pendidikan maupun kelas. Pengembangan kurikulum pada institusi pendidikan pada akhirnya merupakan upaya mewujudkan dan mencapai tujuan pendidikan sebagaimana termuat dalam UUD 1945 yaitu mencerdaskan kehidupan bangsa. Lebih jauh Okoth (dalam Poedjiastutie et al., 2018, hlm. 177) menyatakan bahwa kurikulum mengarahkan guru atau praktisi pendidikan untuk mengelola pelajaran sesuai dengan kebutuhan peserta didik.

Mengingat peran penting dan strategis kurikulum tersebut maka penyusunan kurikulum pendidikan harus memiliki landasan dan arah yang jelas dan terukur. Karena itu pengembang kurikulum di institusi pendidikan tidak saja perlu memahami berbagai model kurikulum mellainkan memahami tujuan dan filsafat pendidikan yang menjadi landasan dan arah pengembangan kurikulum.. Menurut Palupi (2018, hlm. 99) bagi pengembang kurikulum dan sivitas academik yang memiliki perhatian pada kajian kurikulum perlu mengetahui dan menguasai berbagai model kurikulum serta memahami landasan, prinsip dan permasalahannya. Karena setiap institusi pendidikan perlu memiliki kurikulum sendiri maka pimpinan dan para guru di institsi pendidikan wajib memahami dengan benar tujuan dan filsafat pendidikan dalam pengembangan kurikulum.

Penyusunan kurikulum pada institusi pendidikan diarahkan kepada pendapaian tujuan pendidikan. Tujuan pendidikan pada institusi pendidikan terdapat dalam visi, misi, dan tujuan institusi pendidikan. Pengembangan kurikulum harus berlandaskan pada filsafat pendidikan. Sukmadinata (1997, hlm. 56) mengatakan ada empat dasar atau landasan utama dalam pengembangan kurikulum, yaitu: landasan filosofis, landasan psikologis, landasan sosial-budaya dan landasan ilmu pengetahuan dan teknologi. Landasan filsafat terdapat dalam nilai-nilai (values) yang melandasi dan mengarahkan kegiatan pendidikan. Masalah yang dibahas dalam penelitian ini adalah bagaimana tujuan dan filsafat pendidikan dalam kurikulum STKIP Weetebula? Fokus utama penelitian ini penelitian tujuan dan filsafat pendidikan dalam kurikulum STKIP Weetebula dalam perspektif Oliva-Gordon. Maka tujuan penelitian ini adalah (1) menjelaskan tujuan pendidikan dalam kurikulum STKIP Weetebula, (2) menjelaskan filsafat pendidikan dalam kurikulum STKIP Weetebula.

\section{METODE}

Pendekatan dalam penelitian ini adalah penelitian kualitatif. Menurut Sudarwan dalam bukunya Menjadi Peneliti Kualitatif sebagaimana dikutip Shidiq \& Choiri (2019, hlm. 11) langkahlangkah penelitian kualitatif adalah memilih masalah, mengumpulkan bahan yang relevan, menentukan strategi dan pengembangan instrument, mengumpulkan data, menafsirkan data, melaporkan hasil penelitian. Metode yang digunakan dalam penelitian ini adalah metode kepustakaan. Metode kepustakaan adalah serangkaian kegiatan yang berkenaan dengan metode pengumpulan data pustaka, membaca dan mencatat serta mengolah bahan penelitian (Zed, 2008: 15). Menurut C. C. Kuhltau (dalam Putra \& Setiawati, 2020, hlm. 776), langkah-langkah metode kepustakaan adalah pemilihan topik, eksplorasi informasi, menentukan focus penelitian, pengumpulan sumber data, persiapan penyajian data, dan penyusunan laporan. Teknik analisis data yang digunakan dalam penelitian ini adalah teknik analisis isi (content analysis). Analisis konten merupakan sebuah teknik ilmiah untuk memaknai konten. Krippendorff (dalam Rumata, 2017, hlm. 4) mendefinisikan analisis konten sebagai sebuah teknik penelitian 
untuk menyimpulkan makna konten ataupun melalui prosedur yang dapat dipercayai (reliable), dapat diaplikasikan dalam konteks yang berbeda (replicable), serta sah. Dalam analisis ini dilakukan dengan proses memilih, membandingkan, menggabungkan, memilah berbagai pengertiam hingga ditemukan yang relevan.

\section{HASIL DAN PEMBAHASAN}

\section{Hasil}

Penjelasan tentang hasil penelitian meliputi (1) deskripsi tujuan dan filsafat Kurikulum dalam perspektif Oliva-Gordon, (2) deskripsi tujuan dan filsafat kurikulum STKIP Weetebula.

\section{(1) Tujuan dan Filsafat Pendidikan dalam Kurikulum}

Sebelum menjelaskan tujuan pendidikan, Oliva dan Gordon menjelaskan beberapa istilah yang sering digunakan berkaitan dengan tujuan pendidikan. Istilah-istilah tersebut meliputi outcomes, aims, ends, purposes, function, goals, dan objectives (Oliva \& Gordon, 2013, hlm. 119). Outcomes berlaku untuk harapan atau ekspektasi akhir yang bersifat umum. Kata aims disamakan dengan ends, purposes, functions dan goals. Aims atau goals pendidikan sangat luas dan dimaksudkan untuk memberikan arahan umum untuk pendidikan. curriculum goals," Dalam pandangan Oliva dan Gordon tersebut curriculum objectives, instructional goals, dan instructional objectives merupakan entitas berbeda yang memiliki relevansi khusus dengan sistem sekolah.

Curriculum goals dimaknai sebagai ekspektasi umum dan terprogram tanpa kriteria pencapaian. Sedangkan curriculum objectives bersifat lebih spesifik, target terprogram dengan kriteria pencapaian dan, dapat diukur. Curriculum objectives diturunkan dari curriculum goals. Namun, baik curriculum goals dan curriculum objectives berasal dari filosofi dan pernyataan tujuan pendidikan.

Instructional goals merupakan pernyataan target instruksional secara umum tetappi tanpa kriteria pendapaian. Sedangkan instructional objectives merupakan perilaku peserta didik yang diharapkan yang dirumuskan dengan jelas, dapat diamati dan diukur. Instructional objectives berasal dari instructional goals. Dan baik instructional goals maupun instructional objectives berasal dari curriculum goals dan curriculum objectives.

\section{(a) Tujuan Pendidikan}

Menurut United Nations Educational, Scientific, and Cultural Organization (UNESCO) tujuan pendidikan adalah memupuk pemahaman internasional di antara semua manusia di dunia; meningkatkan taraf hidup masyarakat di berbagai negara; memecahkan masalah berkelanjutan yang mengganggu umat manusia, seperti perang, penyakit, kelaparan, dan pengangguran (Oliva \& Gordon, 2013, hlm. 120). Pengembang kurikulum pada institusi pendidikan harus menemukan atau mengembangkan generalisasi atau aturan yang berlaku di situasi pendidikan. Spesialis atau pengembang kurikulum juga harus selalu menyadari bahwa terdapat pengecualian dari aturan-aturan tersebut.

Meskipun demikian, pengembang kurikulum perlu menyadari dan berpegang pada pandangan bahwa pengembangan kurikulum merupakan proses kelompok dan akan lebih efektif sebagai hasil dari proses tersebut. Pengembang kurikulum juga harus mengakui bahwa individu dapat melaksanakan salah satu komponen dari model yang disarankan dalam pengembangan kurikulum. Dengan demikian, pernyataan tujuan tujuan pendidikan dalam konteks pengembangan kurikulum dapat berasal dari individu dan tidak boleh diabaikan oleh kelompok dalam institusi pendidikan Artinya, pernyataan aims, goals, dan objectives pendidikan dan kurikulum mungkin berasal dari individu yang perlu diakomodir dalam institusi pendidikan (Oliva \& Gordon, 2013, hlm. 123) . Dalam konteks inilah model pengembangan kurikulum tidak boleh diinterpretasi untuk meniadakan upaya individu yang spontan dalam pengembangan kurikulum. Justru berbagai ide, gagasan dan input pemikiran dari berbagai pelaku pendidikan di institusi memperkaya dan memperkuat tujuan pendidikan di institusi pendidikan.

Tujuan pendidikan dikenal dan diketahui melalui pernyataan tujuan pendidikan (statement of educational goals). Kita dihadapkan pada tujuan pendidikan ketika kita membaca pernyataan tujuan yang dinyatakan oleh berbagai masyarakat di seluruh dunia, seperti menanamkan nilai-nilai keluarga, mempersiapkan kaum muda menyesuaikan diri dengan masyarakat secara terencana, mendorong usaha secara bebas, menciptakan warga negara yang akan melayani tanah air, mempersiapkan warga negara yang tercerahkan, memperbaiki kekurangan sosial (Oliva \& Gordon, 2013, hlm. 121).

Tujuan pendidikan dapat dinyatakan secara deskriptif ketika seseorang membuat pernyataan seperti pendidikan adalah hidup, bukan persiapan untuk hidup, pendidikan adalah pembentukan nilai-nilai orang muda terhadap 
nilai-nilai orang tua, pendidikan adalah transmisi warisan budaya, pendidikan adalah pelatihan kejuruan, pendidikan adalah seni liberal, pendidikan adalah pelatihan sosialisasi, pendidikan adalah perkembangan intelektual, pendidikan adalah pengembangan pribadi, pendidikan adalah sosialisasi kelompok dan individu, pendidikan adalah pengembangan keterampilan teknologi. Bahkan tujuan pendidikan dinyatakan secara tersirat dalam slogan-slogan seperti jika kamu pikir pendidikan itu mahal, coba untuk tidak mempedulikannya; jika anda dapat membaca papan tanda ini, ucapkan terima kasih kepada guru; pikiran yang sehat dalam tubuh yang sehat.

Tujuan pendidikan dapat dirumuskan dari asesmen kebutuhan anak-anak dan remaja dalam masyarakat, dari haril menganalisis budaya, dan dari mempelajari berbagai kebutuhan masyarakat. Kebutuhan-kebutuhan tersebut dapat ditemukan dalam kehidupan sehari-hari anak-anak dan remaja bahkan masyarakat. tetapi karena masyarakat selalu bersifat heterogen maka kebutuhan dapat sangat bervariasi sesuai dengan kondisi, nilai-nilai dan demografi masyarakat. Heterogenitas tersebut dapat membuat sangat sulit untuk mencapai konsensus tentang tujuan pendidikan dan terutama nilai-nilai yang menjadi sentral tujuan pendidikan. Misalnya bertahuntahun yang lalu National Education Association di Amerika Serikat berusaha mengidentifikasi nilai-nilai moral dan spiritual yang diyakini harus diajarkan di sekolah negeri, dimana dirumuskan 10 nilai antara lain tanggung jawab moral, persetujuan bersama, dan pencapaian kebahagiaan (Oliva \& Gordon, 2013, hlm. 123).

\section{(b) Filsafat Pendidikan}

Filsafat dapat didefinisikan sebagai a way of framing distinctive sorts of questions having to do with what is presupposed, perceived, intuited, believed, and known. Filsafat merupakan cara untuk menyusun berbagai jenis pertanyaan yang berbeda yang berkaitan dengan apa yang diandaikan, dirasakan, diintuisi, dipercaya, dan diketahui. Sedangkan filsafat pendidikan adalah a matter of doing philosophy with respect to the educational enterprise as it engages the educator. Artinya hal melakukan filsafat sehubungan dengan usaha pendidikan karena melibatkan pendidik. Melakukan filosofi pendidikan berarti menjadi sangat sadar akan apa yang terlibat dalam kegiatan pengajaran dan pembelajaran yang kompleks (Greene, 1973, hlm. 7). Pernyataan tujuan pendidikan adalah posisi yang diambil berdasarkan pada sejumlah keyakinan yaitu filosofi pendidikan. Oleh karena itu, tujuan pendidikan adalah pernyataan keyakinan yang menjadi inti dari keyakinan filosofis yang diarahkan pada misi sekolah.

Empat filosofi utama pendidikan menjadi perhatian para pendidik. Ada dua dari filosofi ini yang tampaknya banyak dianut di sekolah saat ini. Empat filosofi tersebut adalah rekonstruksionisme, progresivisme, esensialisme, dan perenialisme. Gambar 2.1 menunjukan empat filosofi utama pendidikan dalam pengembangan kurikulum.

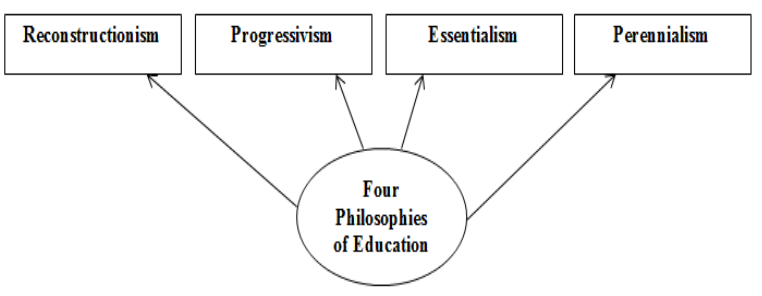

Gambar 2.1: Empat Filosofi Pendidikan (Oliva \& Gordon, 2013

Keempat filosofi pendidikan tersebut dipetakan dari yang paling liberal ke yang paling konservatif seperti yang ditunjukkan pada gambar 2.1. Rekonstruksionisme di paling kiri adalah yang paling liberal dari keempat filosofi dan perenialisme di paling kanan adalah yang paling konservatif. Meskipun esensialisme dan progresivisme telah diterima dan dipraktikkan secara luas oleh para pendidik, namun baik rekonstruksionisme maupun perenialisme tidak mendapat dukungan luas di sekolah-sekolah. Bahkan masyarakat pendidikan Amerika Serikat sangat konservatif untuk mendukung rekonstruksionisme sebagai filosofi yang berlaku dan pada saat yang sama terlalu liberal untuk menerima perenialisme.

Tujuan pendidikan (aims of education) tidak bisa begitu saja dilepaskan, tetapi harus berasal dari pemikiran yang lebih mendasar dan umum tentang nilai, realitas, dan pengetahuan (Butler, 1968, hlm. 487). Bahkan Ornstein \& Hunkins (2018, hlm. 31) mengaitkan filosofi pengembang kurikulum dengan pengalaman hidup, akal sehat, latar belakang sosial dan ekonomi, pendidikan, dan keyakinan umum tentang dirinya dan orang.

1) Rekonstruksionisme

Kata rekonstruksionisme bersal dari bahasa Inggris reconstruct yang berarti menyusun kembali. Dalam konteks filsafat pendidikan rekonstruksionisme merupakan suatu aliran yang 
berusaha merombak tata susunan hidup kebudayaan yang bercorak modern (Haerazi, 2018, hlm. 394). John Dewey menurut Hilda Taba memandang fungsi sekolah melalui kacamata psikologis dan sosial. Dewey dan murid-muridnya memandang pendidikan sebagai seniman yang melihat tanah liat: sebagai media yang melaluinya budaya dapat terus dibentuk dan dibentuk kembali, sebagai pendorong rekonstruksi sosial, bergerak dari mempertahankan status quo untuk mendorong perubahan (Taba, 1962, hlm. 23).

Rekonstruksionisme berpandangan bahwa sekolah tidak sekadar mewariskan warisan budaya atau sekadar mempelajari masalahmasalah sosial, tetapi harus menjadi agen penyelesaian masalah politik dan sosial. Pokok bahasan yang dipelajari dan dibahas oleh peserta didik merupakkan masalah-masalah yang tidak terpecahkan, seringkali kontroversial, seperti pengangguran, kebutuhan kesehatan, kebutuhan perumahan, dan masalah etnis. Konsensus kelompok adalah metodologi yang digunakan untuk mencari solusi atas masalah (Oliva \& Gordon, 2013, hlm. 129).

Banyak pendidik setuju bahwa peserta didik harus membahas masalah sosial, ekonomi, dan politik yang mendesak dan bahkan berusaha mencapai konsensus tentang alternative solusi yang dapat ditempuh. Dengan penekanan yang kuat pada isu-isu sosial yang kontroversial dan premis utama untuk menjadikan sekolah sebagai agen utama untuk perubahan sosial maka rekonstruksionisme belum membuat terobosan besar ke sekolah-sekolah kelas menengah di Amerika Serikat.

2) Perenialisme

Penganut perenialisme kontemporer memandang tujuan pendidikan sebagai pendisiplinan pikiran, pengembangan kemampuan bernalar, dan pencarian kebenaran. Para perennialis memandang bahwa kebenaran itu kekal, abadi, dan tidak berubah. Mereka menganjurkan kurikulum yang sangat akademis dengan penekanan pada tata bahasa, retorika, logika, bahasa klasik dan modern, matematika. Bahkan kaum perennialis sectarian menambahkan studi tentang Alkitab dan teologis dalam kurikulum perennialis. Menurut Assegaf (dalam Siregar, 2016, hlm. 173) filosofi perenialisme beranggapan bahwa pendidikan harus didasari oleh nilai-nilai cultural masa lampau, regressive road to culture oleh karena kehidupan modern saat ini banyak menimbulkan krisis dalam banyak bidang.
Para perenilis menghindari kebutuhan mendesak peserta didik, pendidikan khusus, dan pelatihan kejuruan. Hutchins (1963, hlm. 18) sebagai ekponen pelenialis di Amerika menyatakan bahwa pendidikan yang ideal bukanlah pendidikan ad hoc, bukan pendidikan yang ditujukan untuk kebutuhan mendesak, bukan pendidikan khusus atau pendidikan praprofesional, bukan pendidikan utilitarian. Pendidikan adalah pendidikan yang sengaja untuk mengembangkan pikiran.

3) Essensialisme

Tujuan pendidikan menurut prinsip esensialis adalah transmisi warisan budaya. Berbeda dengan kaum rekonstruksionis yang secara aktif akan mengubah masyarakat, kaum esensialis berusaha untuk melestarikannya. Jika filosofi rekonstruksionisme berusaha menyesuaikan masyarakat dengan manusia, maka kaum esensialis berupaya menyesuaikan peserta didik dengan masyarakat (Oliva \& Gordon, 2013, hlm. 130). Maka dari itu, essensilisme memandang bahwa pendidikan harus berpijak di atas nilai-nilai yang sekiranya dapat mendatangkan kestabilan, telah teruji oleh waktu, tahan lama, serta nilai-nilai yang memiliki kejelasan dan telah terseleksi (Yunus, 2016, hlm. 36). Maka ada 2 hal yang ditekankan oleh filosofi esensialisme yaitu tujuan kognitif (cognitive goals) dan prinsip perilaku (behavioristic principles).

Berkaitan dengan tujuan kognitif, tujuan utama esensialisme adalah kognitif dan intelektual. Pembelajaran yang terorganisir adalah kendaraan untuk transmisi budaya, dan menekankan materi pembelajaran. Konsep 3R (membaca, menulis, berhitung) dan mata pelajaran membentuk inti kurikulum esensialis. Dalam konteks ini jika para progresif yang menyesuaikan kurikulum untuk peserta didik maka sebaliknya kaum esensialis justru menyesuaikan anak dengan kurikulum. Kurikulum materi pelajaran merupakan rencana esensialis untuk pengorganisasian kurikulum. Metode utama yang digunakan adalah AssignStudy-Recite-Test [tugas, belajar, membaca, tes]. Pengetahuan dan kemampuan mereproduksi apa yang telah dipelajari sangat dihargai. Pendidikan dianggap sebagai persiapan untuk suatu tujuan masa depan yaitu melanjutkan ke perguruan tinggi, pekerjaan, dan kehidupan.

Berkaitan dengan prinsip perilaku para esensialis menganut prinsip-prinsip psikologi behaviorisme, dimana menempatkan peserta didik dalam peran pasif sebagai penerima stimulus 
yang harus direspon atau ditanggapi. Behaviorisme digunakan dalam latihan kelas, instruksi terprogram, organisasi pengajaran, tes standar, dan tujuan perilaku. Bahaviorisme juga menekankan pemilihan konten oleh pendidik (guru/dosen) untuk peserta didik dan pemberian penguatan yang segera dan positif. Guru membagi materi pembelajaran dalam bagianbagian yang logis dan berurutan serta menetapkan bagian-bagian yang akan dipelajari oleh peserta didik. Guru memulai pembelajaran dengan memberikan aturan, konsep, atau model kepada peserta didik dan kemudian memberikan banyak kesempatan untuk berlatih (drill) menggunakan panduan atau konsep tersebut. Dengan latihan yang cukup maka peserta didik dapat menggunakan aturan, konsep, modeltersebut kapan pun dibutuhkan. Belajar telah menjadi bagian kebiasaan dari perilaku peserta didik. Meskipun peserta didik lupa akan materi yang telah dipelajari namun materi pebelajaran terebut dapat dengan mudah diingat (retrieved) kembali karena teah dikuasai oleh peserta didik.

\section{4) Progresivisme}

Filosofi progresivisme yang diprakarsai oleh John Dewey, William H. Kilpatrick, John Childs, dan Boyd Bode, menyatakan bahwa sudah saatnya menempatkan materi pembelajaran kepada peserta didik. Peserta didik menjadi pusat sekolah dan pendidikan. John Dewey menyatakan bahwa kebutuhan dan minat peserta didik harus dipertimbangkan dalam pengembangan pendidikan. Peserta didik melibatkan fisik, emosi, dan jiwa di sekolah bersama dengan pikiran mereka. Progresivisme menarik perhatian dan ketekunan para pendidik dalam proses pendidikan. Sejalan dengan pandangan tersebut Salu \& Triyanto (2017, hlm. 30) menyatakan bahwa filosofi progresivisme memandang peserta didik adalah manusia yang memiliki berbagai kemampuan-kemampuan yang potensial dan harus dikembangkan melalui cara-cara yang kreatif dan inovatif.

Pendidikan bukanlah produk yang harus dipelajari (misalnya, fakta dan keterampilan motorik), melainkan sebuah proses yang terus berlanjut selama seseorang hidup. Peserta didik belajar paling baik saat secara aktif mengalami dunianya, bukan menyerap secara pasif materi pembelajaran yang dipilih sebeumnya oleh guru. Jika pengalaman di sekolah dirancang untuk memenuhi kebutuhan dan minat masing-masing peserta didik, maka tidak ada satu pola materi pembelajaran yang sesuai untuk semua peserta didik.
Peserta didik harus menjalani pengalaman pendidikan di sini dan saat ini, mirip dengan ungkapan education is life and learning by doing (Oliva \& Gordon, 2013, hlm. 133). Pendidikan adalah kehidupan dan belajar dengan melakukan. Karena itu sekolah perlu memfasilitasi perbedaan individu peserta didik seperti perbedaan mental, fisik, emosional, spiritual, sosial, dan budaya. Progresivisme menunjukkan kepedulian terhadap peserta didik, masyarakat, dan materi pelajaran, serta menempatkan peserta didik ebagai pusat proses pembelajaran.

\section{(2) Tujuan dan Filsafat Kurikulum STKIP Weetebula dalam Perspektif Oliva- Gordon}

\section{A) Tujuan kurikulum STKIP Weetebula}

Tujuan pengembangan kurikulum STKIP Weetebula termuat baik secara eksplisit maupus secara implisit dokumen Statuta STKIP Weetebula, khususnya dalam visi, misi, dan tujuan STKIP Weetebula.

1) Visi

Visi STKIP Weetebula terdapat dalam pasal 1 Statuta STKIP Weetebula yaitu Menjadikan STKIP Weetebula sebagai Lembaga Pendidikan Tinggi yang menghasilkan Guru profesional yang mampu memberi teladan, membangun kemauan dan mengembangkan kreativitas peserta didik (STKIP Weetebula, 2015, hlm. 5). Visi tersebut dirumuskan berdasarkan komitmen seluruh sivitas akademik, yaitu: menghasilkan guru profesional yang mampu memberi teladan, membangun kemauan dan mengembangkan kreativitas peserta didik. Maka rujuan pengembangan kurikulum STKIP Weetebula adalah guru profesional yang mampu memberi teladan, membangun kemauan dan mengembangkan kreativitas peserta didik. Adapun tujuan tersebut dijelaskan sebagai berikut:

(a) Guru profesional yang mampu memberi teladan

Tujuan ini dirumuskan selaras dengan bab 5 pasal 10 undang-undang nomor 14 tentang guru dan dosen, yaitu menghasilkan guru yang mempunyai kompetensi pedagogik, kompetensi kepribadian, kompetensi professional dan kompetensi sosial. Guru profesional yang dimaksud adalah guru yang mampu menguasai materi pelajaran dengan matang melebihi siswa-siswanya dan mampu memberikan pemahaman kepada mereka secara baik, guru yang mampu menguasai cara-cara menjelaskan dan mengajar. 
Kemugian guru teladan yang dimaksud adalah guru yang melandaskan niat ibadah kepada Tuhan ketika mengajarkan ilmu; guru yang berakhlak mulia, berkelakuan baik, dan menjauhi hal-hal yang bertentangan dengan hal itu, baik di dalam maupun di luar kelas; guru yang mampu mengatur waktu dengan baik; dan guru yang selalu jujur, adil, bertutur katar yang baik, dan memperi nasihat serta pengarahan kepada peserta didik.

(b) Membangun kemauan peserta didik

Guru yang dapat membangun kemauan peserta didik adalah guru yang tampil sebagai motivator bagi siswanya sehingga siswa tidak jenuh dalam belajar. Motivator adalah seseorang yang memberikan motivasi atau semangat baik pada siswa dengan tujuan dapat meningkatkan semangat dan kualitas pembelajaran. Motivasi dapat diartikan sebagai daya penggerak di dalam diri siswa yang minimbulkan, menjamin kelangsungan dan memberikan arah kegiatan belajar, sehingga diharapkan tujuan dapat tercapai.

(c) Mengembangkan kreativitas peserta didik

STKIP Weetebula bertujuan menghasilkan seorang guru yang mampu mengembangkan kreativitas peserta didik, memfasilitasi dan memberikan kesempatan bagi siswa untuk mendemontsrasikan perilak kreatif. Untuk itu hal-hal yang perlu dilakukan guru adalah menghargai hasil-hasil pikiran kreatif siswa; respek terhadap pertanyaan, ide dan solusi siswa yang tidak biasa; menunjukkan bahwa gagasan siswa adalah memiliki nilai yang ditunjukkan dengan cara mendengarkan dan mempertimbangkan.

2) Misi

Berdasarkan visi STKIP Weetebula merumuskan misinya. Misi tersebut terdapat dalam pasal 3 Statuta STKIP Weetebula, yaitu: (1) menyelenggarakan pendidikan dan pengajaran yang berkualitas untuk menghasilkan guru professional; (2) menyelenggarakan penelitian bermutu dan relevan dengan pembangunan bidang pendidikan; (3) menyelenggarakan kegiatan pengabdian pada masyarakat berbasis IPTEKS untuk kemajuan pendidikan: (4) menyelenggarakan sistem pembinaan kemahasiswaan yang berkualitas dalam bidang penalaran dan keilmuan, bakat dan minat serta kesejahteraan mahasiswa; (5) menyelenggarakan sistem manajemen yang dinamis dan profesional, efektif, efisien dan akuntabel; dan (6) mengembangkan kerjasama dalam bidang pendidikan dengan institusi lain baik secara lokal, nasional maupun internasional (STKIP Weetebula, 2015, hlm. 5).

3) Tujuan

Berlandaskan visi dan misi tersebut STKIP Weetebula merumuskan tujuan. Tujuan STKIP Weetebula terdapat dalam pasal 4 Statuta STKIP Weetebula, yaitu: (1) memenuhi kebutuhan tenaga pendidik yang profesional yang memiliki kompetensi yang handal baik dari segi substansi maupun metodologi serta memiliki kualifikasi sesuai dengan ketentuan perundangundangan yang berlaku; (2) menghasilkan lulusan yang bermutu, khususnya tenaga kependidikan yang mampu mengaplikasikan ilmu pengetahuan, teknologi, dan seni yang disesuaikan/berorientasi pada kebutuhan daerah; (3) mengembangkan kemitraan dengan berbagai institusi terkait seperti sekolah, instansi/departemen dan industri, baik pemerintah maupun swasta guna mengantisipasi lapangan pekerjaan alternative untuk tenaga lulusan; (4) meningkatkan relevansi dan mutu penelitian dan pengabdian pada masyarakat dengan melaksanakan program pendidikan dan pelatihan; (5) mengembangkan budaya ilmiah untuk penciptaan suasana dan lingkungan ilmiah yang kondusif bagi semua komponen civitas akademika guna tercapainya Tri Dharma Perguruan Tinggi; (6) meningkatkan kesejahteraan civitas akademika guna menunjang kelancaran tugas demi peningkatan kualitas layanan; (7) mengembangkan penalaran, minat dan kegemaran mahasiswa guna terwujudnya perkembangan kepribadian tenaga lulusan (STKIP Weetebula, 2015, hlm. 5).

Tujuan STKIP juga terdapat dalam Statuta STKIP Weetebula bab IV tentang penyelenggaraan pendidikan, khususnya dalam pasal 14 yang menyatakan bahwa pendidikan akademik program sarjana STKIP Weetebula diarahkan untuk menghasilkan lulusan yang memiliki kualifikasi sebagai berikut: (1) bersifat jujur, bertanggung jawab, mampu bekerja sama, disiplin dan memiliki hati nurani serta empati; (2) menguasai dasar-dasar berpikir ilmiah dan memiliki keterampilan dalam bidang keahlihan tertentu sehingga mampu menemukan, memahami, menjelaskan, dan merumuskan cara penyelesaian masalah yang ada di masyarakat di dalam kawasan keahlihannya; (3) mampu menerapkan ilmu pengetahuan dan keterampilan yang dimilikinya sesuaii dengan bidang keahlihannya dalam kegiatan produktif dan pelayanan kepada masyarakat dengan sikap dan perilaku yang sesuai dengan tata kehidupan bersama; (4) mampu bersikap dan berperilaku 
dalam membawa diri dalam berkarya pada bidang keahlihannya maupun dalam kehidupan bersama di masyarakat (STKIP Weetebula, 2015, hlm. 11).

\section{B) Filosofi Kurikulum STKIP Weetebula}

Landasan filosofi pengembangan kurikulum STKIP Weetebula tercermin pada karakteristik STKIP Weetebula dalam pasal 5 Statuta STKIP Weetebula yang disebut sebagai nilai-nilai inti (core values) STKIP Weetebula, yaitu: (1) menjunjung tinggi martabat luhur manusia (kemanusiaan); (2) mencari dan menyatakan kebenaran; (3) nilai-nilai katolisitas yang bersumber pada dokumen gereja dan ex corde ecclesiae; (4) tanggung jawab, kerja keras, rasa memiliki lembaga, pengabdian; (5) pamomong (membimbing/mendampingi mahasiswa dan kolega); (6) tata krama, etika, budi pekerti; (7) cerdas (intelektual, emosional, spiritual dan sosial); (8) religius/beriman (cinta tuhan, sesama dan alam); (9) profesional (memiliki kompetensi kepribadian, sosial, pedagogik, profesional); (10) harmoni dalam keberagaman (STKIP Weetebula, 2015, hlm. 5).

Selain itu filosofi STKIP Weeebula tercermin pada semboyan "bersama kita bisa" [together we can] yang dicetuskan oleh para pendiri STKIP Weetebula. Semboyan tersebut mencerminkan filosofi dan karakteristik masyarakat Sumba yang ingin dilestarikan oleh STKIP Weetebula. Kehidupan masyarakat Sumba diwarnai oleh semangat gotong royong. Semangat "bersama kita bisa" ini dilestarikan, dilaksanakan dalam penyelenggaraan pendidikan di STKIP Weetebula bahkan sampai pada unit-unit terkecil.

\section{Pembahasan}

\section{(1) Tujuan Kurikulum STKIP Weetebula}

Tujuan kurikulum STKIP weetebula terdapat dalam visi, misi, dan tujuan STKIP Weetebula. Dalam visi STKIP Weetebula tamak tujuan pengembangan kurikulum yaitu mmenghasilkan guru profesional yang mampu memberi teladan, mampu membangun kemauan peserta didik, serta mengembangkan kreativitas peserta didik. Visi STKIP untuk menghasilkan guru professional sejalan dengan pasal 1 UndangUndang nomor 14 tahun 2005 yang menyatakan bahwa guru adalah pendidik profesional dengan tugas utama mendidik, mengajar, membimbing, mengarahkan, melatih, menilai, dan mengevaluasi peserta didik pada pendidikan anak usia dini jalur pendidikan formal, pendidikan dasar, dan pendidikan menengah. Guru sebagai pendidik professional mendidik, mengajar, membimmbing, mengarahkan, melatih, menilai peserta didik untuk mengembangkan potensi-potensinya secara utuh dan optimal. Menurut Susanto sebagaimana diikutip Aprillinda (2019, hlm. 604) guru professional memiliki tantanga di era revolusi industri 4.0 yaitu (1) teaching in multicultural society, yaitu mengajar di tengah masyarakat yang memiliki beragam budaya dengan kompetensi multi bahasa; (2) teaching for the construction of meaning, yaitu mengajar untuk mengkonstruksi makna (konsep); (3) teaching for active learning, yaitu mengajar untuk pembelajaran aktif; (4) teaching and technology, yaitu mengajar dan teknologi; (5) teaching with new view about abilities, yaitu mengajar dengan pandangan baru mengenai kemampuan; (6) teaching and choice, yaitu mengajar dan pilihan; dan (7) teaching and accountability, yaitu mengajar dan akuntabilitas. Kurikulum STKIP Weetebula perlu didesain untuk menghasikan guru professional di era revolusi industry 4.0 bahkan segera mempersiapkan lulusan untuk memasuki era society 5.0.

Selanjutnya, dalam misi STKIP Weetebula dinyatakan bahwa tujuan pengembangan kurikulum menjadi lebih spesifik yaitu (1) pendidikan dan pengajaran yang berkualitas untuk menghasilkan guru profesional; (2) penelitian bermutu dan relevan dalam bidang pendidikan; (3) kegiatan pengabdian pada masyarakat berbasis IPTEKS, dan (4) sistem pembinaan kemahasiswaan yang berkualitas dalam bidang penalaran dan keilmuan, bakat dan minat serta kesejahteraan mahasiswa (STKIP Weetebula, 2015, hlm. 5). Berkaitan dengan pendidikan dan pengajaran yang berkualitas, Supriatna (2013, hlm. 16) menyatakan bahwa kualitas pembelajaran secara operasional dapat diartikan sebagai intensitas keterkaitan sistemik dan sinergis dosen, mahasiswa, kurikulum dan bahan belajar, media, fasilitas, serta sistem pembelajaran dalam menghasilkan proses dan hasil belajar yang optimal sesuai dengan tuntutan kurikulum. Maka untuk menciptakan proses pendidikan dan pembelajaran yang berkualitas untuk menghasilkan guru professional STKIP weetebula perlu mendesain dan mengimplementasikan sinergi yang berkualitas seluruh komponen pendidikan termasuk ketersediaan dan optimalisasi segala fasilitas pendidikan yang tersedia.

Berkaitan dengan peningkatan kualitas penelitian mahasiswa maka STKIP Weetebula perlu memfasilitasi mahasiswa membangun budaya ilmiah dan riset. Pengembang kurikulum perlu mendesain kurikulum yang mendorong kegiatan ilmiah danpenelitian mahasiswa. 
Pelaksanaan penelitian dan publikasi mahasiswa 9 (dan dosen) berkaitan erat dengan kaidah-kaidah proses ilmiah dalam menyelesaikan sebuah masalah ilmiah. Hal ini selaras dengan Hidayat (2018, hlm. 38) menyatakan bahwa proses ilmiah merupakan suatu rangkaian pembuktian secara logika dan matematis untuk mencari solusi terhadap permasalahan yang didapat. Pengetahuan dibangun atas dasar suatu konstruksi/langkah langkah dalam pemecahan masalah. Menurut Gauch (2003, hlm. 41) proses ilmiah membentuk empat karakteristik yang menyatu dalam bidang ilmu sains, yaitu rationality, truth, objectivity, dan realism. Misi desain kurikulum STKIP Weetebula memberi tempat yang proporsional kegiatan penelitian melalui berbagai kegiatan akademik, kegiatan observasi, dan penelitian mahasiswa, atau penelitian bersama dosen dan mahasiswa, bahkan penelitian bersama lintas program studi dan institusi.

Salah satu tri dharma perguruan tinggi adalah pengabdian kepada masyarakat. Maka salah satu misi STKIP adalah kegiatan pengabdian pada masyarakat berbasis IPTEKS (STKIP Weetebula, 2015, hlm. 5). Jika penelitian merupakan kegiatan penemuan, penciptaan dan pengembangan IPTEKS maka pengabdian kepada masyarakat merupakan kegiatan penerapan ilmu pengetahuan, teknologi dan seni (IPTEKS) yang meliputi kegiatan pengembangan, penyebarluasan dan pembudayaan IPTEKS. Hal ini berkaitan dengan perguruan tinggi sebagai salah satu pusat pengkajian dan pengembangan IPTEKS dalam masyarakat. Menurut Riduwan (2016, hlm. 95) hakikat pengabdian kepada masyarakat oleh perguruan tinggi adalah (1) pengembangan dan penyebarluasan IPTEKS menjadi produk yang secara langsung dapat dimanfaatkan oleh masyarakat; (2) Penerapan IPTEKS secara benar dan tepat sesuai dengan tuntutan kebutuhan masyarakat; (3) pemberian bantuan keahlian dalam mengidentifikasi masalah yang dihadapi serta mencari alternatifalternatif pemecahannya dengan menggunakan pendekatan ilmiah; (4) pemberian jasa pelayanan profesional dalam berbagai bidang permasalahan yang memerlukan penanganan secara cermat dengan menggunakan keahlian yang belum dimiliki oleh masyarakat pengguna. Kegiatan pengabdian kepada masyarakat dalam kurikulum STKIP Weetebula perlu mendorong mahasiswa (dan dosen) untuk mengembangkan dan menerapkan IPTEKS kepada masyarakat, mengatasi masalah-masalah dalam masyarakat dengan pendekatan ilmiah, melayani berbagai kebutuhan dan masalah masyarakat yang penting dan relevan.

Kemudian tujuan pengembangan kurikulum juga tampak dalam tujuan STKIP Weetebula sebagaimana termuat dalam Statuta STKIP Weetebula, yaitu (1) menghasilkan lulusan berkualitas yang mampu mengaplikasikan ilmu pengetahuan, teknologi, dan seni yang sesuai kebutuhan daerah, (2) mengembangkan budaya dan lingkungan ilmiah kondusif bagi semua komponen civitas akademika, (3) mengembangkan penalaran, minat dan kegemaran mahasiswa guna terwujudnya perkembangan kepribadian lulusan (STKIP Weetebula, 2015, hlm. 5)

\section{A) Filosofi Kurikulum STKIP Weetebula}

Filosofi STKIP Weetebula terdapat dalam cove values STKIP weetebula sebagaimana terdapat dalam pasal 5 Statuta STKIP Weetebula. Menurut Titus et al. (1984, hlm. 11) filosofi adalah sekumpulan sikap dan kepercayaan terhadap kehidupan dan alam yang biasanya diterima secara tidak kritis. Pandangan tersebut menggarisbawahi bahwa makna filosofi merupakan kumpulan nilai dalam kehidupan yang diyakini, diterima dan dijalani. Dalam pengembangan kurikulum, filosofi memberikan manfaat yang sangat besar, sebagaimana dikatakan Kristiawan (2016, hlm. 6) yaitu filosofi sebagai dasar dalam bertindak; 2) sebagai dasar dalam mengambil keputusan, mengurangi salah paham dan konflik, persiapan menghadapi situasi dunia yang selalu berubah, dan menjawab keraguan.

Filosofi pendidikan tampak dalam nilainilai yang dianut oleh institusi pendidikan. Menurut Lakshmi \& Paul (2018, hlm. 29) nilai merupakan prinsip atau standar perilaku yang dapat membantu seseorang untuk menilai apa yang penting dalam hidupnya. Nilai mencerminkan sikap, pilihan, keputusan, penilaian, hubungan, impian, dan visi seseorang terhadap kehidupannya dan lingkungan sekitarnya. Jack R. Fraenkel (dalam Syafeie, 2020,hlm. 63) menyatakan bahwa value is an idea-a concept-about what someone thinks is important in life. When a person values something, he or she seems it worthwhile-worth having, worth doing, or worth trying to obtain. Nilai dipandang sebagai suatu ide atau konsep tentang segala sesuatu yang berharga dalam kehidupan. Ketika seseorang menghargai sesuatu, sesuatu tampaknya layak untuk dimiliki, layak dilakukan, atau pantas untuk dicoba. Sedangkan Lickona (dalam Suyatno et al., 2019, 
hlm. 609; Wening, 2012, hlm. 58) menggambarkan bahwa nilai itu kelihatan (visible). Nilai meliputi sifat baik sebagai wujud perilaku moral yang sesuai. Nilai merupakan wujud perilaku konkrit atau penerapan akhlak. Akhlak baik yang melandasi moral disebut sebagai nilai yang diwujudkan dalam bentuk perilaku yang terlihat.

Mahasiswa STKIP Weetebula dibentuk dan didik berlandaskan pada vore values bahkan seluruh proses penyelenggaraan pendidikan di STKIP Weetebula dijiwai oleh core values tersebut. Pengembangan kurikulum dan penyelenggaraan pendidikan di STKIP Weetebula memiliki landasan filosofi melalui nilai-nilai inti tersebut. Hal ini dinyatakan Winarso $(2017$, hlm. 7) bahwa perkembangan kurikulum senantiasa berpijak pada konsep filosofi sehingga memberikan warna terhadap konsep dan implementasi kurikulum yang dikembangkan.

Dalam perspektif Oliva -Gordon filsafat pendidikan yang melandasi pengembangan kurikulum meliputi rekonstruksionisme, perennialisme, essensialisme, dan progressivisme. Rekonstruksionisme dipandang sebagai filosofi yang paling liberal, sedangkan perenialisme dipandang sebagai filosofi yang paling konservatif. Filsafat rekonstruksionisme memandang bahwa pendidikan harus menjadi agen perubahan sosial, pendidikan menjadi agen menyelesaiakn masalah sosial dan politik dalam masyarakat. Peserta didik harus membahas masalah-masalah sosial politik dalam proses pembelajaran. Para pendidik menyajikan berbagai masalah sosial-politik yang perlu didiskusikan, didebatkan untuk menemukan solusi-solusi yang relevan. Metode-metode seperti pembelajaran kolaboratif, pemecahan masalah, penemuan sangat relevan bagi proses pembelajaran. Solusi yang dihasilkan unautk mengatasi masalahmasalah tersebut ditetapkan berdasarkan kesepakatan dalam kelompok (group consensus). Pendidik dapat menjadi fasilitator dan motivator pembelajaran yang mendorong penemuan solusi terhadap masalah-masalah yang dibahas dalam pembelajaran.

Berdasarka uraian tersebut maka rekonstruksionisme tampak dalam semboyan "bersama kita bisa" dan secara eksplisit dalam core values STKIP Weetebula seperti menjunjung tinggi martabat luhur manusia, mencari dan menyatakan kebenaran, harmoni dalam keberagaman, tanggung jawab, kerja keras, pengabdian, dan cerdas. Lulusan yang telah menginternalisasikan dan dapat mewujudkan nilai-nilai tersebut baik dalam kehidupan pribadi maupun dalam menjalani profesi sebagai guru akan mampu memberikan solusi-solusi terhadap masalah-masalah sosial kemasyarakatan. Karena itu mahasiswa perlu memiliki kemampuan pemecahan masalah yang baik. Ketika mahasiswa menganalisis dan memecahkan masalah yang disajikan dalam pembelajaran mahasiswa dihadapkan dengan beberapa tantangan seperti kesulitan dalam memahami masalah dan akar masalah, menemukan solusi terbaik terhadap masalah yang dibahas. Untuk itu Menurut Saad dan Ghani (dalam Cahyani \& Setyawati, 2016, hlm. 153) menyarankan agar mahasiswa perlu melakukan beberapa hal seperti menerima tantangan dari masalah, merencanakan strategi penyelesaian masalah, menerapkan strategi, dan menguji kembali solusi yang diperoleh. Hal ini sesuai dengan pendapat Polya (1973, hlm. 5) bahwa ada empat tahap pemecahan masalah yaitu memahami masalah, merencanakan penyelesaian masalah, melakukan perencanaan masalah, dan melihat kembali hasil yang diperoleh.

Berkaitan dengan harmoni dalam keberagaman, secara fatual kerukunan hidup antar umat beragama di Indonesia khususnya masih menghadapi banyak hambatan dalam pencapaianya. Berbagai perbedaan yang merupakan kekayaan bangsa sering menimbulkan konflik horizontal dalam kehidupan bermasyarakat. Selain itu di tengah-tengah beragam persoalan bangsa tersebut bangsa Indonesia masihh bergelut dengan masalah kemiskinan, pengangguran, korupsi, serta ketidakadilan ekonomi, hukum, dan sosial. Karena itu masalah kerukunan hidup antar umat beragama bukan hanya menjadi tanggung jawab pemerintah semata melainkan tanggungjawab seluruh masyarakat termasuk masyarakat pendidikan tinggi. Perbedaan menyangkut agama, suku, ras, bahasa, daerah, golongan sosial, dan tingkat ekonomi telah lama menjadi isu penting di Indonesia (Sefriyono, 2014, hlm. 1). Maka nilai harmony in diversity sebagai salah satu core values STKIP Weetebula sangat relevan dipelajari, disikusikan, diinternalisasikan dan diwujudkan oleh sivitas akademika STKIP Weetebula. Internalisasi dan perwujudan nilai keharmonisan dalam keberagaman sejak dari masa pendidikan akan membentuk pandangan dan siikap mahasiswa untuk menghargai keberagaman tersebut. Penghargaan terhadap keberagaman mendorong mereka menciptakan keharmonisan dalam keberagaman di tengah masyarakat. 
Esensi perennialisme dalam pendidikan adalah pandangan tentang tujuan pendidikan sebagai pendisiplinan pikiran, pengembangan kemampuan bernalar, dan pencarian kebenaran. Penganut perennialisme mengembangkan kurikulum akademis dengan penekanan pada tata bahasa, retorika, logika, bahasa klasik dan modern, matematika. Bahkan kaum perennialis sektarian menekankan studi tentang Alkitab dan teologis dalam kurikulum perennialis. Pandangan perennialisme ini sesuai dengan cove values STKP Weetebula yaitu mencari dan menyatakan kebenaran dan mengembangkan kecerdasan, antara lain kecerdasan intelektual atau kognitif. Binet sebagaimana dikutip Suryabrata (dalam Hidayat, 2011, hlm. 243) mengasumsikan bahwa seseorang yang cerdas cenderung memiliki nilai yang lebih tinggi dibandingkan dengan mereka yang kurang atau tidak cerdas. Maka tugas pengembang kurikulum adalah mendesain kurikulum untuk memfasilitasi pengembangan kecerdasan intelektual mahasiswa melalui proses pembelajaran. Selanjutnya, perennialisme menekankan pencarian kebenaran, khususnya kebenaran intelektual. Menurut Wahana (2008, hlm. 276) kebenaran pengetahuan dapat bersumber antara lain dari fakta empiris (kebenaran empiris), wahyu atau kitab suci (kebenaran wahyu), fiksi atau fantasi (kebenaran fiksi). Kebenaran pengetahuan perlu dibuktikan dengan sumber atau asal dari pengetahuan terkait. Cara atau sarana untuk memperoleh kebenaran pengetahuan, antara lain dapat menggunakan indera (kebenaran inderawi), akal budi (kebenaran intelektual), intuisi (kebenaran intuitif), iman (kebenaran iman). Sedangkan tingkat pengetahuan yang diharapkan dan diperolehnya yaitu pengetahuan biasa sehari-hari (ordinary knowledge), pengetahuan ilmiah (scientific knowledge) menghasilkan kebenaran ilmiah, dan pengetahuan filsafati (philosofical knowledge) menghasilkan kebenaran filsafat. Core values STKIP yang lain adalah pengembangan kemampuan bernalar. Menurut Permana dan (dalam Merona \& Santi, 2018, hlm. 115) penalaran merupakan proses berpikir dalam proses penarikan kesimpulan. Penalaran merupakan proses berpikir yang berusaha mengkaitkan fakta dan/atau bukti-bukti yang diketahui menuju kepada suatu kesimpulan. Sebenarnya pengembangan kemampuan bernalar berkaitan dengan pencarian dan penemuan kebenaran ilmiah yang sangat penting bagi mahasiswa dalam meningkatkan kecerdasannya.

Secara etimologi esensialisme berasal dari bahasa Inggris yakni essential yang berarti inti atau pokok dari sesuatu, dan ism berarti aliran, mazhab atau paham (Thaib, 2015, hlm. 733). Prinsip essensialisme adalah transmisi warisan budaya. Jika konstruksionisme berusaha mengubah masyarakat, sebaliknya essensialisme berusaha untuk melestarikan nilai-nilai budaya. Anggota masyarakat harus menyesuaikan dengan berbagai warisan budaya dan tradisi yang hidup dalam masyarakat. Jika konstruksionisme menyesuaikan kurikulum terhadap karakteristik mahasiswa, maka essensialisme menyesuaikan mahasiswa dengan karakteristik kurikulum yang berlaku. Maka kurikulum akademik membentuk inti kurikulum esensialis. Karena itu kurikulum materi pelajaran merupakan rencana pengorganisasian kurikulum. Metode utama yang digunakan adalah penugasan, belajar, membaca, tes (assign-study-recite-test). Pengetahuan, kemampuan mereproduksi apa yang telah dipelajari, sangat dihargai, dan pendidikan dianggap sebagai persiapan untuk suatu tujuan masa depan yaitu melanjutkan ke perguruan tinggi, pekerjaan, dan kehidupan.

Ciri-ciri esensialisme dalam pendidikan menurut William C. Bagley sebagaimana dikutip Thaib (2015, hlm. 740) adalah (1) minat-minat yang kuat dan tahan lama sering tumbuh dari upaya-upaya belajar awal yang memikat atau menarik perhatian bukan karena dorongan dari dalam diri siswa; (2) pengawasan pengarahan, dan bimbingan orang yang dewasa adalah melekat dalam masa balita yang panjang atau keharusan ketergantungan yang khusus pada spesies manusia; (3) kemampuan untuk mendisiplin diri harus menjadi tujuan pendidikan, maka menegakan disiplin adalah suatu cara yang diperlukan untuk mencapai tujuan tersebut; (4) esensialisme menawarkan sebuah teori yang kokoh, kuat tentang pendidikan. Sedangkan Khobir sebagaimana dikutip Helaludin (dalam Hardanti, 2020, hlm. 89) menyatakan bahwa filsafat esensialisme memiliki prinsip-prinsip pendidikan yaitu: (1) pendidikan lebih menekankan pada kedisiplinan; (2) dosen dituntut inisiatif dalam suatu pembelajaran; (3) pendidikan merupakan proses asimilasi dari subject matter yang ditentukan; (4) sekolah harus tetap mempertahankan metode pembelajaran tradisional khususnya yang berkaitan dengan kedisiplinan; (5) kesejahteraan umum merupakan tujuan dari pendidikan.

Filsafat essensialisme ini tampak dalam core values STKIP Weetebula seperti nilai tata krama, etika, budi pekerti; nilai menjunjung 
tinggi martabat luhur manusia (kemanusiaan); nilai religius/beriman (cinta tuhan, sesama dan alam); nilai katolisitas yang bersumber pada dokumen gereja dan ex corde ecclesiae serta pengembangan kompetensi kepribadian dan sosial mahasiswa sebagai calon guru. Pengembangan kedisiplinan mahasiswa dibangun melalui pedoman kode etik mahasiswa. Pengembangan bakat dan minat tampak dalam berbagai mata kuliah pilihaan yang ditawarkan kepada mahasiswa di prodi-prodi serta kegiatankegatan ekstrakurikuler yang diwadahi oleh unit kegiatan mahasiswa program studi. Penanaman pengetahuan tentang teori-teori pendidikan dilaksanakana melalui berbagai mata kuliah kependidikan dan keguruan yang menjadi cirikhas STKIP. Mahasiswa difasilitasi untuk menguasai materi perkuliahan baik teoritis maupun praktek untuk meningkatkan kompetensi sebagai calon guru melalui berbagai metode yang relevan. Perkuliahan tatap muka dilaksanakan secara tertib hingga pelaksanaan ujian untuk mengukur penguasaan mahasiswa terhadap mataeri pembelajaran. Nilai-nilai katolisitas dilestarikan melalui mata kuliah agama katolik, kegiatan keagamaan dengan tetap menghargai agama yang dianut mahasiswa.

Dalam pandangan progressivisme, pendidikan dimaknai sebagai upaya yang sengaja dilakukan untuk membantu pertumbuhan dan perkembangan peserta didik. Pendidikan bukan hanya mentransformasikan pengetahuan melainkan peserta didik bisa memahami realitas kehidupan yang akan terjadi di masa depan sesuai dengan kebutuhan (Ruslan, 2018, hlm. 211). Selanjutnya, Kneller (1971, hlm. 134) menyatakan bahwa prinsip pendidikan progresivisme adalah (1) pendidikan adalah hidup itu sendiri, bukan persiapan untuk hidup. kehidupan yang baik adalah kehidupan intelegen yaitu kehidupan yang mencakup interpretasi dan rekonstruksi pengalaman; (2) pengajaran harus secara langsung dihubungkan dengan berbagai kepentingan peserta didik; (3) belajar melalui pemecahan masalah harus didahulukan dari belajar melalui subject matter; (4) peran pendidik tidak langsung tetapi untuk memberikan petunjuk kepada peserta didik; (5) sekolah perlu mendorong kerjasama dibanding kompetisi.

Pengembangan kurikulum di STKIP Weetebula dalam perspektif progresivisme perlu mengembangkan kemandirian mahasiswa, membangkitkan kepercayaan dir sebagai calon guru, mahasiswa difasilitasi untuk peka terhadap masalah dan kebutuhan dalam dunia pendidikan dsan kurikulum khususnya kebutuhan dan masalah psikologis dan masalah belajar siswa, mahasiswa mampu menerapkan pengetahuan dan keterampilan yang diperolehnya dalam kehidupan baik sebagai guru maupun sebagai anggota masyarakat. hal ini sejalan dengan pendapat Nanuru (2013, hlm. 136) menyatakan bahwa kurikulum progressivisme sangat menekankan bahwa peserta didik difasilitasi menjadi pribadi yang mandiri (independen), menjadi seorang pemikir yang percaya diri. Peserta didik dibimbing belajar dan mempelajari persoalan-persoalan yang dianggap paling menarik melalui pemilihan pokok persoalan yang hendak dipelajari, kemudian menetapkan konsep dan definisi bagi dirinya sendiri atas persoalan yang dipelajari, selanjutnya mengekspresikan apa yang dirasakan dan diyakini. Peran pendidik adalah membantu peserta didik belajar dan mendisplinkan peserta didik agar tetap konsekuen dengan pilihan yang menarik.

\section{KESIMPULAN}

Berdasarkan uraian tentang tujuandan filsafat kurikulum di atas maka dapat disimpulkan sebagai berikut.

1. Tujuan pendidikan dalam kurikulum menurut perspektif Oliva-Gordon meliputi tujuan umum (global aims), pernyataan tujuan (statement of purposes), dan asal dari tujuan (derivation of aims). Sedangkan filsafat pendidikan dalam kurikulum adalah rekonstruksionisme (reconstructionism), progresivisme (progressivism), esensialisme (essentialism), dan perenialisme (perennialism).

2. Tujuan pendidikan dalam kurikulum STKIP berdasarkan beberapa dokumen STKIP Weetebula terdapat dalam visi, misi, dan tujuan STKIP Weetebula

3. Filosofi pendidikan dalam kurikulum STKIP Weetebula terjkandung dalam nilai-nilai inti (core values) dan semboyan "bersama kita bisa" yang membentuk karakteristik STKIP Weetebula.

4. Tujuan dan filosofi pendidikan dalam kurikulum STKIP Weetebula tersebut kemudian dijabarkan dalam dokumendokumen kurikulum maupun penyelenggaraan pendidikan khususnya pada tingkat program studi, bahkan dalam kegiatan-kegiatan pendidikan lainnya.

\section{SARAN}

Berdasarkan hasil penelitian ini sebagaimana termuat dalam kesimpulan 
penelitian maka penulis menyampaikan saran sebagai berikut

1. Penyusunan kurikulum STKIP Weetebula perlu dilaksanakan berdasarkan kajian tentang tujuan dan filsafat pendidikan.

2. Tujuan dan filsafat pendidikan tersebut dapat digali dari berbagai kebutuhan dan permasalahan peserta didik, kearifan lokal di sumba, serta selaras dengan filosofi dan nilai-nilai luhur bangsa Indonesia

\section{DAFTAR PUSTAKA}

Alawiyah, F. (2013). Peran Guru dalam Kurikulum 2013. Jurnal Aspirasi, 4(1), 65-74.

http://jurnal.dpr.go.id/index.php/aspirasi /article/view/480

Aprillinda, M. (2019). Perkembangan Guru Profesional Di Era Revolusi Industri 4.0. Prosiding Seminar Nasional Pendidikan Program Pascasarjana Universitas PGRI Palembang, 600-608.

Butler, J. D. (1968). Four Philosophies and Their Practice in Education and Religion (3rd ed). New York: Harper \& Row.

Cahyani, H., \& Setyawati, R. W. (2016). Pentingnya Peningkatan Kemampuan Pemecahan Masalah Melalui PBL Untuk Mempersiapkan Generasi Unggul Menghadapi MEA. PRISMA, Prosiding Seminar Nasional Matematika X Universitas Negeri Semarang, 151-160.

Gauch, H. (2003). Scientific Method in Practice. London: University Press Cambridge.

Greene, M. (1973). Teacher as Stranger: Educational Philosophy for the Modern Age. Belmont, Calif: Wadsworth.

Haerazi. (2018). Landasan Filosofis Pembelajaran Bahasa Inggris di Indonesia. Jurnal Ilmu Sosial Dan Pendidikan, 2(1), 391-396.

Hardanti, B. W. (2020). Landasan Ontologis, Aksiologis, Epitesmologis Aliran Filsafat Esensialisme Dan Pandanganya Terhadap Pendidikan. Reforma: Jurnal Pendidikan Dan Pembelajaran Pembelajaran, 9(2), 87-95. https://doi.org/https://doi.org/10.30736/
Tujuan dan filosofi yang termuat dalam statuta STKIP Weetebula perlu diterjemahkan dan dijabarkan secara tepat dalam dokumen kurikulum sebagai dokumen kurikulum tertulis serta dalam implementasi kurikulum melalui proses pembelajaran khususnya pada tingkat program studi dan pada kegiatan-kegiatan ekstrakurikuler.

rf.v9i2.320

Hidayat, S. (2018). Peningkatan Mutu Penelitian Di Indonesia Dalam Mengatasi Masalah Pendidikan. Bioilmi: Jurnal Pendidikan, 4(2), 34-44. https://doi.org/10.19109/bioilmi.v4i2.28 72

Hidayat, U. (2011). Peran Kecerdasan Intelektual Dan Self Regulated Learning Terhadap Prestasi Belajar Mahasiswa. Psympathic: Jurnal Ilmiah Psikologi, 4(1), 240-251. https://doi.org/10.15575/psy.v4i1.2193

Hutchins, R. M. (1963). On Education. Santa Barbara, Calif: Center For the Study of Democratic Institutions.

Kneller, G. F. (1971). Introduction To The Philosophy Of Education. Calivornia: University of California.

Kristiawan, M. (2016). Filsafat Pendidikan: The Choice Is Yours. Yogyakarta: Valia Pustaka.

Lakshmi, V. V., \& Paul, M. M. (2018). Value Education in Educational Institutions and Role of Teachers in Promoting the Concept. International Journal of Educational Science and Research, 8(4), 29-38. https://doi.org/10.24247/ijesraug20185

Merona, S. P., \& Santi, E. E. (2018). Pengembangan Instrumen Asesmen Penalaran Matematis Pada Matakuliah Fungsi Kompleks. Fibonacci: Jurnal Pendidikan Matematika Dan Matematika, 4(2), 113-122.

Nanuru, R. F. (2013). Progresivisme Pendidikan dan Relevansinya di Indonesia. Jurnal Uniera, 2(2), 132143.

Oliva, P. F., \& Gordon, W. (2013). 
Developing the Curriulum. Boston: Pearson.

Ornstein, A. C., \& Hunkins, F. P. (2018). Curriculum: Foundation, Principles and Issue (Global Edi). London \& New York: Pearson.

Palupi, D. T. (2018). What Type of Curriculum Development Models Do We Follow? An Indonesia's 2013 Curriculum Case. Indonesian Journal of Curriculum and Educational Technology Studies, 6(2), 98-105. https://doi.org/10.15294/ijcets.v6i2.269 54

Poedjiastutie, D., Akhyar, F., Hidayati, D., \& Gasmi, F. N. (2018). Does Curriculum Help Students to Develop Their English Competence? A Case in Indonesia. Arab World English Journal, 9(2), 175-185. https://doi.org/10.24093/awej/vo19no2.1 2

Polya, G. (1973). How to Solve It. New Jersey: Princeton University Press.

Putra, A. F., \& Setiawati, D. (2020). Studi Kepustakaan Penerapan Konseling Cognitive Information Processing (CIP) Dalam Lingkup Pendidikan. Jurnal BK UNESA, 11(5), 773-784. https://jurnalmahasiswa.unesa.ac.id/ind ex.php/jurnal-bkunesa/article/view/36060/32069

Riduwan, A. (2016). Pelaksanaan Kegiatan Pengabdian Kepada Masyarakat Oleh Perguruan Tinggi. Ekuitas: Jurnal Ekonomi Dan Keuangan, 3(2), 95-107. https://doi.org/10.24034/j25485024.y19 99.v3.i2.1886

Rumata, V. M. (2017). ANALISIS ISI KUALITATIF TWITTER "\#TaxAmnesy" dan "\#AmnestiPajak." Jurnal Penelitian Komunikasi Dan Pembangunan, 18(1), 1-7. https://doi.org/10.31346/jpkp.v18i1.840

Ruslan. (2018). Perspektif Aliran Filsafat Progresivisme Tentang Perkembangan Peserta Didik. Jurnal Ilmu Sosial Dan Pendidikan, 2(2), 211-217.

Salu, V. R., \& Triyanto. (2017). Filsafat Pendidikan Progresivisme dan Implikasinya dalam Pendidikan Seni di
Indonesia. Imajinasi: Jurnal Seni, 11(1), 29-42.

Sefriyono. (2014). Harmoni dalam Perbedaan: Strategi Pengelolaan Keberagaman Beragama. Turast: Jurnal Penelitian \& Pengabdian, 2(1), 1-16.

Shidiq, U., \& Choiri, M. (2019). Metode Penelitian Kualitatif di Bidang Pendidikan. In Journal of Chemical Information and Modeling (Vol. 53, Issue 9). Ponorogo: CV Nata karya. http://repository.iainponorogo.ac.id/484 /1/METODE

PENELITIAN KUALITATIF DI BIDANG PENDIDIKAN.pdf

Siregar, R. L. (2016). Teori Belajar Perenialisme. Al-Hikmah: Jurnal Agama Dan Ilmu Pengetahuan, 13(2), 172-183. https://doi.org/10.25299/alhikmah:jaip.2016

STKIP Weetebula. (2015). Statuta STKIP Weetebula. Weetebula: Yayasan Pendidikan Nusa Cendana.

Sukmadinata, N. S. (1997). Pengembangan Kurikum: Teori dan Praktek. Bandung: Remaja Rosdakarya.

Supriatna, A. R. (2013). Meningkatkan Kualitas Pembelajaran Melalui Active Learning In High Education (Alihe) Pada Mata Kuliah Pendidikan IPA SD di Jurusan PGSD FIP UNJ. Jurnal Perspektif Ilmu Pendidikan, 27(1), 1521.

Suyatno, Jumintono, Pambudi, D. I., Mardati, A., \& Wantini. (2019). Strategy of Values Education in the Indonesian Education System. International Journal of Instruction, 12(1), 607-624. https://doi.org/https://doi.org/10.29333/i ji.2019.12139a

Syafeie, A. K. (2020). Internalisasi NilaiNilai Iman Dan Taqwa Dalam Pembentukan Kepribadian Melalui Kegiatan Intrakurikuler. Al-Tarbawi AlHaditsah: Jurnal Pendidikan Islam, 4(1), $\quad$ 60-75. https://doi.org/10.24235/tarbawi.v5i1.6 280

Taba, H. (1962). Curriculum Development: Theory and Practice. New York: 
Harcourt Brace Jovanovich.

Thaib, M. I. (2015). Essensialisme Dalam Perspektif Filsafat Pendidikan Islam. Jurnal Mudarrisuna, 4(2), 731-762.

Titus, H. H., Marilyn, S. S., \& Richard T, N. (1984). Persoalan-Persoalan Filsafat. Terjemahan Rasjidi. Jakarta: Bulan Bintang.

Undang-Undang Nomor 14 Tahun 2005 Tentang Guru dan Dosen.

Wahana, P. (2008). Menguak Kebenaran Ilmu Pengetahuan Dan Aplikasinya Dalam Kegiatan Perkuliahan. Jurnal Filsafat, 18(3), 273-294. https://doi.org/10.22146/jf.3528

Wening, S. (2012). Pembentukan Karakter Bangsa Melalui Pendidikan Nilai. Jurnal Pendidikan Karakter, 2(1), 55-66. https://doi.org/https://doi.org/10.21831/j pk.v0i1.1452

Winarso, W. (2017). Dasar Pengembangan Kurikulum Sekolah. Cirebon: IAIN Syekh Nurjati.

Yunus, H. A. (2016). Telaah Aliran pendidikan Progresivisme dan Esensialisme Dalam Perspektif Filsafat Pendidikan. Jurnal Cakrawala Pendasakrawala Pendas, 2(1), 29-39. 